\title{
Microbial protein synthesis
}

By P. C. Thомas, The Hannah Research Institute, Ayr KA6 ${ }_{5} H L$

Because of the extensive hydrolysis of dietary proteins in the rumen and the attendant wastage of nitrogen which is absorbed as ammonia across the rumen wall and excreted as urea in the urine, the ruminal synthesis of bacterial and protozoal proteins has a special importance in the nutrition of the ruminant. This paper considers the factors influencing microbial protein synthesis in simple in vitro systems and examines the problems of quantifying the effects of nutrition and other factors on protein synthesis in the rumen.

\section{In vitro studies}

Bauchop \& Elsden (1960) reported that for several anaerobic bacteria, grown in batch culture under optimum conditions, where energy alone was limiting, the yield of dry bacterial cells was on average $10.5 \mathrm{~g} / \mathrm{mol}$ ATP produced by substrate fermentation and, since bacteria contain about $10.5 \% \mathrm{~N}$, this represents about $\mathrm{I} \cdot \mathrm{I} g$ bacterial N/mol ATP. The growth of a wide range of bacteria, including some rumen organisms, has now been investigated and for many the yields of dry matter/ mol ATP (molar growth yield or $\mathrm{Y}_{\text {ATP }}$ ) are close to the value of 10.5 (see Forrest, I969; Stouthamer, 1969; Forrest \& Walker, 1970; Payne, 1970). Some workers have considered this figure as a biological 'constant' (see Payne, 1970) but, even under optimum conditions, values vary between organisms from 8.5 to $13 . \mathrm{I} \mathrm{g} / \mathrm{mol}$ (about $0.9-1.4 \mathrm{~g} \mathrm{~N} / \mathrm{mol}$ ). For some species, including the rumen bacteria Selenomonas ruminantium and Bacteroides amylophilus, yields of $\mathrm{I}^{-20} \mathrm{~g} / \mathrm{mol}$ have been reported (Hobson \& Summers, 1967), but there are uncertainties about ATP production by these organisms and recently it has been suggested that their true growth yields lie between 9 and $\mathrm{I} 2 \mathrm{~g} / \mathrm{mol}$ (Hobson \& Summers, 1972).

Where nutrients other than energy are limiting $\mathrm{Y}_{\mathrm{ATP}}$ may be much less than 10.5 . For Zymomonas mobilis grown on glucose $\mathrm{Y}_{\mathrm{ATP}}$ was $8.6 \mathrm{~g} / \mathrm{mol}$ in a complex medium but only $4 \cdot \mathrm{I} \mathrm{g} / \mathrm{mol}$ in a minimal medium (Senez \& Belaich, 1965 ). Similarly, when $\mathrm{N}$ (Belaich \& Senez, 1965) or pantothenic acid (Belaich, Belaich \& Simonpietri, 1972) was deficient, growth was impaired and the efficiency of the system was low. It was interesting that with pantothenic acid deficiency the reduction in growth was related to an uncoupling of the utilization of ATP (Ladzunski \& Belaich, 1972); with the $\mathrm{N}$ deficiency, ATP production was depressed (Belaich \& Senez, 1965).

'Environmental' factors also influence $\mathrm{Y}_{\mathrm{A} T \mathrm{TP}}$ and variations in efficiency occur with changes in incubation temperature (Senez, 1962; Forrest, 1967) and, in con- 
tinuous culture systems, with dilution rate. If a low dilution rate or some other environmental factor impairs growth, the energy used for maintenance by the organisms becomes a significant part of the total energy expenditure (Pirt, 1965) and the efficiency of utilization of energy is reduced.

Protozoa are probably less efficient than bacteria in protein synthesis and are more susceptible to nutrient deficiencies. Their ability to interconvert or synthesize amino acids is very limited (Abou Akkada \& Howard, 1962; Coleman, 1967a,b; Wallis \& Coleman, 1967; Coleman, 1969) and they need purine and pyrimidine bases for nucleic acids (Coleman, 1968). In mixed cultures they engulf bacteria and release the $\mathrm{N}$ which is not incorporated into protozoal proteins back into the medium (Coleman, 1964; Coleman \& Hall, I966), where it may be used to synthesize new bacterial protein. This process itself must be energetically wasteful but its actual effect is difficult to assess because the incorporation of bacterial protein into protozoa is fairly efficient and engulfment may increase the effective dilution rate of the system and improve the efficiency of bacterial growth.

\section{Synthesis of microbial protein in the rumen}

Protein synthesis in the rumen will be influenced by the factors which are important in vitro: nutrient supply, microbial population and culture conditions. However, any detailed analysis of the process is prevented by the technical problems of obtaining meaningful measurements of bacterial and protozoal synthesis, and by the complexity of a system in which the microbial population, culture conditions and supplies of energy and other nutrients can fluctuate widely with time.

Methods of investigation. The determination of bacterial and protozoal proteins in digesta in the presence of partially degraded dietary protein is a major technical problem. A wide variety of techniques has been used to distinguish between food and microbial proteins including differences in their solubility, lysine and organic phosphorus contents (see Ibrahim \& Ingalls, 1972); determinations based on microbial nucleic acids (Ellis \& Pfander, 1965 ; Smith \& McAllan, I970) and on the incorporation of ${ }^{35} \mathrm{~S}$ or ${ }^{15} \mathrm{~N}$ into the microbes have been developed (Pilgrim, Gray, Weller \& Belling, 1970; Mathison \& Milligan, I971; Harrison, Beever \& Thomson, 1972). These methods suffer because they do not readily separate the bacteria and protozoa and even where physical separations have also been used there must be reservations about their application to the partially disintegrated microbes found in the post-ruminal stomach and duodenum. Bacterial and protozoal proteins have been determined using $\alpha$ - $E$-diaminopimelic acid $(\alpha-\epsilon-D A P)$, an amino acid found only in the bacteria, and amino ethyl phosphonic acid (AEP), which is present only in protozoa (see Ibrahim \& Ingalls, 1972). The need to allow for differences in concentration of these marker acids between microbial species has been stressed elsewhere (Hutton, Bailey \& Annison, 1971) but there may be more fundamental objections to their use for measuring protein synthesis from the flow of protein from the rumen. The fate of $\alpha$-E-DAP from bacteria which are engulfed by protozoa is not clear, although the acid is not incorporated into the protozoal protein, and the significance of bacterial degradation of dead or ruptured protozoa is unknown. 
Nutrient requirements. Nutrient requirements vary with the microbial species, and the types and numbers of organisms are influenced by the diet and by conditions in the rumen (Hobson, 1972; Thomas \& Clapperton, 1972). With natural diets containing adequate vitamins and minerals for the host animal the elements most likely to be deficient for the microbes are $\mathrm{N}$ and possibly sulphur, although there could be growth factors in food for which microbes have a special requirement. As the crude protein content of the diet is reduced, or where the $\mathrm{N}$ is largely nonprotein, microbial synthesis may be limited by amino acids or fatty acids, the carbon skeletons of which are needed for the synthesis of valine, leucine, isoleucine, phenylalanine and tryptophan (Chalupa, I968). The concentrations at which nutrients become limiting are not clearly defined and definition may be prevented because of changes in the composition of the microflora with changes in nutrition. This effect should tend to maximize protein synthesis but, because other factors also influence the microbes, a species of organism may be retained in the rumen despite deficiencies in its nutrition.

Energy requirement. The energy available to the microbes will vary with the amount of food fermented and the ATP produced. Quantitative aspects of digestion in the rumen have been reviewed elsewhere (Thomas \& Clapperton, 1972) and there are several detailed considerations of the calculation of ATP production (Walker, 1965; Baldwin, Lucas \& Cabrera, 1970; Forrest \& Walker, 1970). However, it should be pointed out that such calculations involve much greater assumptions about the yields of ATP from particular metabolic transactions than are involved in simple in vitro systems with a single bacterium. If ATP production from carbohydrate is calculated by the method of Walker ( 1965 ) but allowance is made for ATP produced by methanogenesis, ATP yields/mol hexose fermented vary by only about $10 \%$ between the extremes of fermentation pattern observed in the rumen. If, however, the production of propionic acid is linked to a more efficient synthesis of ATP, such as that indicated for Selenomonas ruminantium (Hobson \& Summers, 1972), ATP production will vary appreciably with fermentation pattern.

Nutrient balance. Since all nutrients are not released from the food at the same rate and since the waste-products of one organism are the substrates for another, nutrient supply to a particular microbial species can vary widely after feeding. Maximum use of ammonia, derived from non-protein $\mathrm{N}$ sources, occurs when carbohydrate fermentation takes place at the same rate as ammonia production (see Blackburn, I965), and the storage of polysaccharides by bacteria and protozoa may play an important role in synchronizing the supplies of energy and other nutrients, especially $\mathrm{N}$ which may be absorbed from the rumen and then recycled.

Estimates of synthesis in vivo. Despite the difficulties involved, in recent years a considerable effort has been directed towards measuring protein synthesis in the rumen. To allow for the effect of energy on microbial growth, the amount of protein produced has generally been expressed as a function of either the organic matter $(\mathrm{OM})$ apparently digested in the rumen, i.e. the OM 'disappearing' between the food and the duodenum (see Thomas \& Clapperton, 1972), or of the OM truly digested, i.e. the $\mathrm{OM}$ 'disappearing' plus the $\mathrm{OM}$ incorporated into the microbes. 
The latter method is more correct and facilitates calculations of ATP production but the former is more precise and has a wider application where information on the $\mathrm{OM}$ incorporated into bacteria and protozoa is incomplete. Assuming $\mathrm{Y}_{\mathrm{ATP}}$ is 10.5 and ATP is produced, as calculated by Walker ( $\mathrm{I}^{6} 6_{5}$ ), and by methanogenesis, energy-limited bacterial synthesis corresponds to about $27 \mathrm{~g}$ bacterial $\mathrm{N} / \mathrm{kg} \mathrm{OM}$ truly digested or to about $3^{6} \mathrm{~g} \mathrm{~N} / \mathrm{kg}$ OM apparently digested.

Detailed information on the production of microbial protein is limited but a large number of experiments have been done to determine the flow of total protein from the rumen in sheep fitted with omasal, abomasal or duodenal cannulas. From 50 to $80 \%$ of dietary protein is thought to be degraded in the rumen (Smith, 1969) and therefore the flow of total protein should reflect microbial synthesis.

Fig. I shows $\mathrm{N}$ flow from the rumen related to the $\mathrm{N}$ content of the diet for a wide range of foods. For high-protein diets $\mathrm{N}$ flow is high and presumably reflects the presence of undigested dietary proteins. For normal and low-protein diets, and particularly for cereal diets, flows are much more variable and in several instances values are less than could be produced by the bacteria alone. Whether this inefficiency is due to nutrient deficiencies or to other factors is not clear.

Hume and his colleagues, in an excellent series of experiments using minimal protein diets containing urea and given in frequent meals throughout the day, have examined the effects of nutrition on protein synthesis. For diets containing 35,63 , 120 and $216 \mathrm{~g}$ crude protein $/ \mathrm{kg} \mathrm{OM}$ the microbial $\mathrm{N}$ flowing from the rumen was respectively $17^{\circ} 9,19^{\circ} 6,22^{\circ} 4$ and $25^{\circ} 3 \mathrm{~g} / \mathrm{kg}$ OM apparently digested (Hume, Moir \& Somers, 1970). It was interesting that ruminal digestion of $\mathrm{OM}$ was similar with all diets, implying that only microbial anabolism was impaired by $\mathrm{N}$ deficiency. In further experiments (Hume, 1970a,b; Hume \& Bird, 1970), the rate of protein synthesis was increased progressively through dietary additions of branched-chain fatty acids, soluble proteins, or soluble proteins + sulphur. Rates equal to those of about $3^{6} \mathrm{~g} \mathrm{~N} / \mathrm{kg}$ OM apparently digested were recorded (see Fig. r) and with diets containing casein and zein rates were even higher, although these may reflect contamination of the microbial protein fraction with small amounts of undigested dietary protein. Similar rates of about $3^{6}$ and $28 \mathrm{~g} \mathrm{~N} / \mathrm{kg}$ OM apparently digested have been determined by Mathison \& Milligan (197I) using a ${ }^{15} \mathrm{~N}$ method in sheep 'continuously' fed diets of barley or of hay.

Walker \& Nader (1970) have also measured synthesis isotopically but with ${ }^{35} \mathrm{~S}$ and in animals given a forage ration once daily. Under these conditions synthesis declined to a minimum at about $8 \mathrm{~h}$ after feeding and then increased towards the next meal; there were complementary changes in the concentration of polysaccharide in the microbes. Over $24 \mathrm{~h}$, the average rate of synthesis corresponded to about $3 \circ \mathrm{g} \mathrm{N} / \mathrm{kg}$ OM apparently digested but the maximum rate was about $37 \mathrm{~g} \mathrm{~N} / \mathrm{kg} \mathrm{OM}$ apparently digested.

The relative contribution of bacteria and protozoa to the total microbial protein is difficult to judge and will clearly vary with the diet, Weller, Pilgrim \& Gray, ( 1962 ) estimated that in sheep given hay diets, protozoal protein could vary from $5 \%$ of the microbial protein in the rumen $3 \mathrm{~h}$ after feeding to $40 \% 24 \mathrm{~h}$ after feeding. 


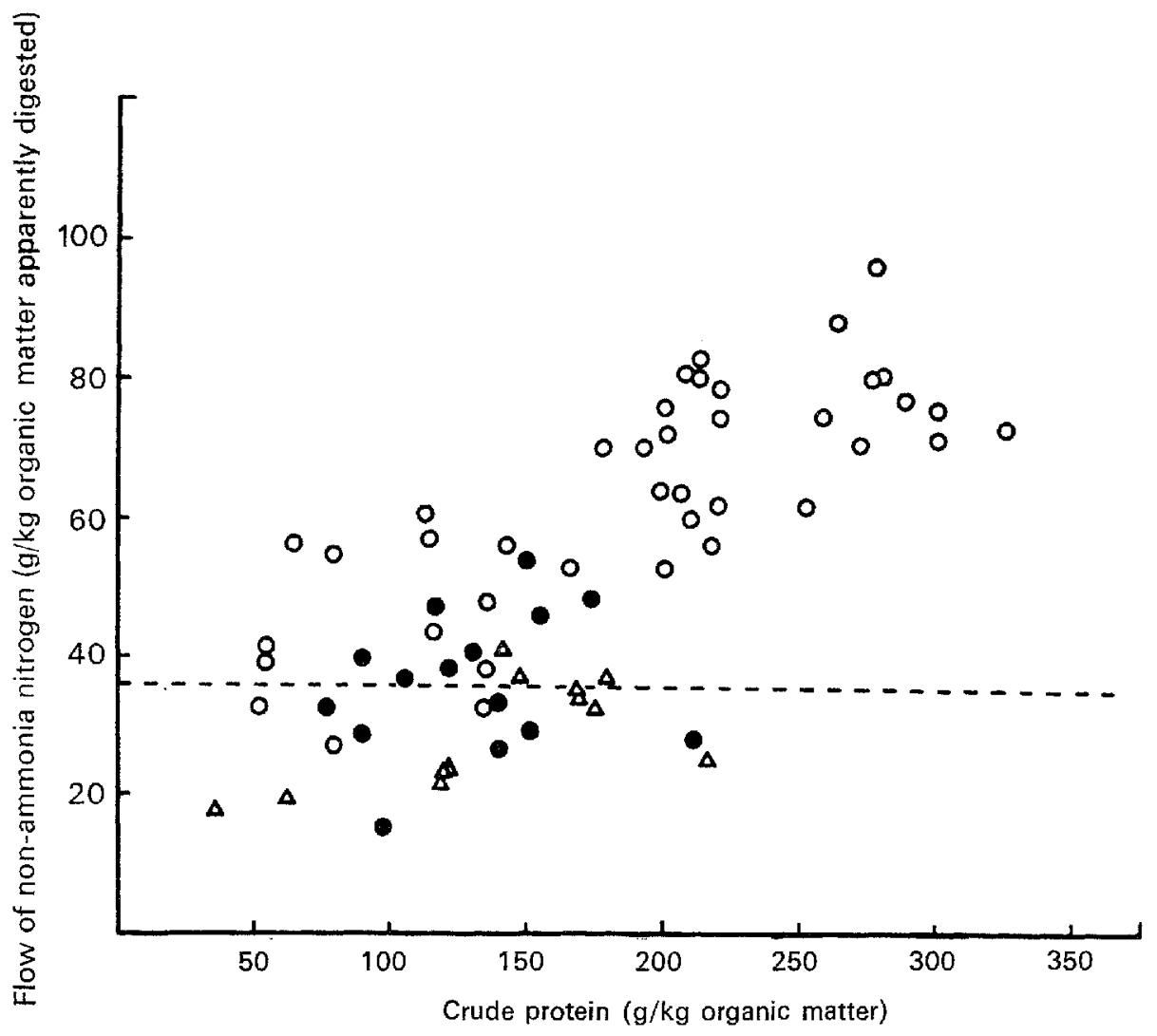

Fig. r. The flow of non-ammonia nitrogen from the rumen and the crude protein content in the diet. $O$, forage diets; $O$, diets containing cereals; $\Delta$, semi-purified diets containing non-protein $N$. The broken line indicates a rate of synthesis of $36 \mathrm{~g} \mathrm{~N} / \mathrm{kg}$ OM. Values, which have been adjusted for secretion of $\mathrm{N}$ into the abomasum by subtraction of $\mathrm{I} \mathrm{g} \mathrm{N} / \mathrm{d}$, are based on the results of Hogan $\&$ Weston (1967a,b; 1969, I971); Weston \& Hogan (1968a, b; 1971); Hogan, Weston \& Lindsay (1969); Nicholson \& Sutton (1969); Hume (r970a,b); Hume \& Bird (1970); Hume, Moir \& Somers (1970); Ishaque, Thomas \& Rook (I97I); Jackson, Rook \& Towers (r97r); Beever, Coclho da Silva, Prescott \& Armstrong (1972); Coelho da Silva, Seeley, Beever, Prescott \& Armstrong (1972); Lindsay \& Hogan (1972); Ørskov, Fraser \& McDonald (1972).

More recently, Ibrahim \& Ingalls (I972), using $\alpha-\in-D A P$ and AEP, have reported that in animals given mixed hay and barley diets in frequent meals throughout the day $44 \%$ of ruminal microbial $N$ was protozoal. These values are surprisingly high in view of the large percentage of bacterial protein, often more than $70 \%$, in the total protein flowing from the rumen (see e.g. Ørskov, Fraser \& McDonald, 1972). It is possible that the grazing habits of the protozoa encourage their movement from one undigested food mass to another and their preferential retention in the rumen.

The efficiency of bacterial protein synthesis has been estimated from the flow of $\alpha-E-D A P$ from the rumen but in the absence of information on the protozoa these estimates may not be very accurate and in vivo values for $\mathrm{Y}_{\mathrm{ATP}}$ such as those derived by Hogan \& Weston (1970) may be misleading. The apparent efficiency of bacterial $32(2) 4$ 
synthesis ( $\mathrm{g} \mathrm{N} / \mathrm{kg}$ OM apparently digested) in sheep given lucerne or red clover diets was increased by $20-35 \%$ by defaunation (Lindsay \& Hogan, 1972) and with other diets even larger differences might be observed. A summary of the results of determinations of bacterial protein synthesis from $\alpha-E$-DAP indicates that for a range of twenty-seven diets the average bacterial synthesis corresponds to $32 \cdot 1 \mathrm{~g} \mathrm{~N} / \mathrm{kg} \mathrm{OM}$ apparently digested but values vary between diets from 15.3 to $53^{\cdot} \cdot 1 \mathrm{~g} \mathrm{~N} / \mathrm{kg} \mathrm{OM}$ (Weston \& Hogan, 1968b; Hogan, Weston \& Lindsay, I969; Hogan \& Weston, 1970; Weston \& Hogan, 1971; Ishaque, Thomas \& Rook, 1971; Jackson, Rook \& Towers, 1971; Ørskov et al. 1972; Lindsay \& Hogan, 1972). In two experiments with diets based on cereals (Ishaque et al. I971; Jackson et al. 1971) and in one with purified foods (Hume, 1970a), synthesis has been correlated with the mixture of short-chain fatty acids in the rumen. The basis of this effect is unknown but the relationship probably reflects fundamental variations in the energetics of fermentation associated with a change in the composition of the bacterial population or in the balance between the bacteria and protozoa.

I am grateful to Professor J. A. F. Rook and to Dr C. Harfoot for their helpful discussion in the preparation of this paper.

\section{REFERENCES}

Abou Akkada, A. R. \& Howard, B. H. (I962). Biochem. J. 82, 3 I 3 .

Baldwin, R. L., Lucas, H. L. \& Cabrera, R. (1970). In Physiology of Digestion and Metabolism in the Ruminant p. 3 19 [A. 'T. Phillipson, editor]. Newcastle upon Tyne: Oriel Press.

Bauchop, T. \& Elsden, S. R. (1960). F. gen. Microbiol. 23, 457.

Beever, D. E., Coelho da Silva, J. F., Prescott, J. H. D. \& Armstrong, D. G. (1972). Br. F. Nutr. 28, 347.

Belaich, J. P. \& Senez, J. C. (1965). Colloques int. Cent. natn. Rech. scient. 156, $38 \mathrm{x}$.

Belaich, J. P., Belaich, A. \& Simonpietri, P. (1972). F. gen. Microbiol. 70, 179.

Blackburn, T. H. (1965). In Physiology of Digestion in the Ruminant p. 322 [R. W. Dougherty, editor]. Washington, DC: Butterworths.

Chalupa, W. (1968). F. Anim. Sci. 27, 207.

Coelho da Silva, J. F., Seeley, R. C., Beever, D. E., Prescott, J. H. D. \& Armstrong, D. G. (1972). Br. F. Nutr. 28, 357 .

Coleman, G. S. (1964). F. gen. Microbiol. 37, 209.

Coleman, G. S. (1967a). F. gen. Microbiol. 47, 433 .

Coleman, G. S. (1967b). F. gen. Microbiol. 47, 449 .

Coleman, G. S. (1968). F. gen. Microbiol. 54, 83 .

Coleman, G. S. (1969). F. gen. Microbiol. 57, $3 \circ 3$.

Coleman, G. S. \& Hall, F. J. (I g66). J. gen. Microbiol. 44, iii.

Ellis, W. C. \& Pfander, W. H. (r965). Nature, Lond. 205, 974.

Forrest, W. W. (1967). F. Bact. 94, 1459.

Forrest, W. W. (1969). In Microbial Growth p. 65 [P. Meadow and S. J. Pirt, editors]. London: Cambridge University Press.

Forrest, W. W. \& Walker, D. J. (r970). A. Rev. Microbiol. Physiol. 5, 2 I3.

Harrison, D. G., Beever, D. E. \& Thomson, D. J. (1972). Proc. Nutr. Soc. 31, 60A.

Hobson, P. N. (1972). Proc. Nutr. Soc. 31, I35.

Hobson, P. N. \& Summers, R. (1967). $\mathscr{7}$. gen. Microbiol. 47, 53.

Hobson, P. N. \& Summers, R. (1972). F. gen. Microbiol. 70, 35 I.

Hogan, J. P. \& Weston, R. H. (1967a). Aust. F. agric. Res. 18, $80_{3}$.

Hogan, J. P. \& Weston, R. H. (1967b). Aust. F. agric. Res. 18, 973. 
Hogan, J. P. \& Weston, R. H. (I969). Aust. F. agric. Res. 20, 347.

Hogan, J. P. \& Weston, R. H. (I 970). In Physiology of Digestion and Metabolism in the Ruminant p. 474

[A. T. Phillipson, editor]. Newcastle upon Tyne: Oriel Press.

Hogan, J. P. \& Weston, R. H. (1971). Aust. F. agric. Res. 22, 95 I.

Hogan, J. P., Weston, R. H. \& Lindsay, J. R. (I969). Aust. F. agric. Res. 20, 925.

Hume, I. D. (1970a). Aust. Y. agric. Res. 21, 297.

Hume, I. D. (1970b). Aust. F. agric. Res. 21, 305.

Hume, I. D. \& Bird, P. R. (1970). Aust. F. agric. Res. 21, 3 r5.

Hume, 1. D., Moir, R. J. \& Somers, M. (1970). Aust. J. agric. Res. 21, 283.

Hutton, K., Bailey, F. J. \& Annison, E. F. (1971). Br. F. Nutr. 25, 165.

Ibrahim, E. A. \& Ingalls, J. R. (1972). J. Dairy Sci. 55, 971.

Ishaque, M., Thomas, P. C. \& Rook, J. A. F. (I97I). Nature, New Biology, 23r, 253.

Jackson, P., Rook, J. A. F. \& Towers, K. G. (1971). F. Dairy Res. 38, 33 .

Ladzunski, A. \& Belaich, J. P. (1972). J. gen. Microbiol. 70, 187.

Lindsay, J. R. \& Hogan, J. P. (I972). Aust. F. agric. Res. 23, 32 I.

Mathison, G. W. \& Milligan, L. P. (197I). Br. F. Nutr. 25, 35I.

Nicholson, J. W. G. \& Sutton, J. D. (1969). Br. F. Nutr. 23, 585.

Orskov, E. R., Fraser, C. \& IMcDonald, I. (1972). Br. F. Nutr. 27, 491.

Payne, W. J. (r970). A. Rev. Microbiol. 24, 17.

Pilgrim, A. F., Gray, F. V., Weller, R. A. \& Belling, C. B. (1970). Br. F. Nutr. $24,5^{89}$.

Pirt, S. J. (1965). Proc. R. Soc, 163B, 224.

Senez, J. C. \& Belaich, J. P. (1965). Colloques int. Cent, natn. Rech. scient. 124, 357.

Senez, J. C. (1962). Bact. Rev. 26, 95.

Smith, R. H. (Ig69). F. Dairy Res. 36, $3^{13}$.

Smith, R. H. \& McAllan, A. B. (1970). Br. F. Nutr. 24, 545.

Stouthamer, A. H. (I 669 ). In Methods in Microbiology p. 629 [J. R. Norris and D. W. Ribbons, editors]. London: Academic Press.

Thomas, P. C. \& Clapperton, J. L. (1972). Proc. Nutr. Soc. 31, 165.

Walker, D. J. (1965). In Physiology of Digestion in the Ruminant p. 296 [R. W. Dougherty, editor]. Washington, DC: Butterworths.

Walker, D. J. \& Nader, C. J. (1970). Aust. F. agric. Res. 21, 747.

Wallis, O. C. \& Coleman, G. S. (x967). F. gen. Microbiol. 49, 315.

Weller, R. A., Pilgrim, A. F. \& Gray, F. V. (1962). Br. F. Nutr. r6, 83.

Weston, R. H. \& Hogan, J. P. (I968a). Aust. F. agric. Res. 19, 567.

Weston, R. H. \& Hogan, J. P. (1968b). Aust. F. agric. Res. 19, 963.

Weston, R. H. \& Hogan, J. P. (197I). Aust. F. agric. Res. 22, 139. 